\title{
Konferencja na temat edukacji wielokulturowej (Akademia im. Jana Długosza w Częstochowie, 16-17 maja 2010)
}

W dniach 16-17 maja 2010 r. w Akademii im. Jana Długosza w Częstochowie odbyła się VI Międzynarodowa Konferencja Naukowa pt. „Edukacja wielokulturowa wyzwaniem dla nauk o wychowaniu". Jej organizatorem był Zakład Historii i Teorii Wychowania. W konferencji uczestniczyli naukowcy zajmujący się problematyką wielokulturowości. Znaleźli się wśród nich pedagodzy, socjolodzy, psycholodzy, historycy oświaty oraz politolodzy z wielu znaczących ośrodków akademickich, m.in. z uniwersytetów we Lwowie, Hamburgu, Gdańsku, Poznaniu, Wrocławiu, Katowicach, Kielcach oraz wielu innych uczelni wyższych. Reprezentowali oni szeroki zakres metodologii badań społecznych, co dało możliwość wielostronnego oświetlenia badanych problemów wielokulturowości.

W pierwszym dniu konferencji odbyły się Warsztaty Jasnogórskie. Zwiedzający Bibliotekę Jasnogórską oraz inne obiekty zabytkowe na terenie klasztoru jasnogórskiego dyskutowali na temat wkładu tego ośrodka religijnego w rozwój kultury narodowej. Następnie uczestnicy konferencji wzięli udział we mszy świętej w kaplicy Cudownego Obrazu Matki Boskiej Częstochowskiej.

W poniedziałek 17 maja w Sali Senatu AJD miała miejsce uroczystość Jubileuszu 80-lecia prof. Janusza Sztumskiego, której przewodniczył rektor AJD, prof. Zygmunt Bąk. Adres gratulacyjny wygłosili i złożyli na ręce Jubilata prezydent Częstochowy, rektorzy Politechniki Częstochowskiej oraz GWSH w Katowicach, a prof. K. Rędziński wygłosił laudację na cześć prof. Janusza Sztumskiego.

Obradom plenarnym w części popołudniowej konferencji przewodniczył Andrzej Kozera. W ich trakcie referaty wygłosili: Janusz Jarosiński (Uniwersytet HumanistycznoPrzyrodniczy im. J. Kochanowskiego w Kielcach) „Problemy cywilizacyjne wsi świętokrzyskiej u progu XXI wieku”, Grażyna Mendecka (Uniwersytet Śląski, Górnośląska Wyższa Szkoła Handlowa w Katowicach), „Twórczość - wielokulturowość - globalizacja”; Danuta Borecka-Biernat (Uniwersytet Wrocławski), „Rodzinne dyskryminanty konstruktywnych i destruktywnych strategii radzenia sobie w sytuacji konfliktu interpersonalnego” oraz Ireneusz Świtała (AJD), „W poszukiwaniu szczęścia według Kazimierza Twardowskiego".

Kolejna część obrad została zorganizowana w trzech sekcjach.

Obradom sekcji „Psychologia i socjologia wychowania” przewodniczyła Grażyna Mendecka (UŚ). Referaty wygłosili: Jan Nikołajew (Uniwersytet Gdański), „Problematyka socjologii morskiej”; Krzysztof Czekaj (Górnośląska Wyższa Szkoła Handlowa w Katowicach), „Socjografia miejska w województwie śląskim”; Elżbieta Napora (AJD), „Samotna matka w ocenie synów i córek”; Elżbieta Kornacka-Skwara (AJD), „Komunikacja międzykulturowa w kontekście komunikowania się w rodzinie"; Agata Woźniak-Krakowian, Joanna Górna (AJD), „Edukacja przez całe życie - psychologiczne i społeczne determinanty”; Edyta Widawska (AJD), „Znaczenie animacji społecznej w pracy pedagogicznej”; Izabela Gomółka-Walaszek (AJD), „Emocjonalność bliźniąt w parach”; 
Aleksandra Papaj (Powiatowa Poradnia Psychologiczno-Pedagogiczna w Częstochowie), „O kolorach, kształtach, dźwiękach i innych tworzywach arteterapii”.

Sekcji pedagogicznej przewodniczył Wiesław Jamrożek (Uniwersytet im. Adama Mickiewicza w Poznaniu i ŁWSH w Żarach). Wygłoszono następujące referaty: Krzysztof Jakubiak (Uniwersytet Gdański), „Charakter narodowy Polaków i jego konsekwencje wychowawcze w świetle polskiego piśmiennictwa z końca XIX i początków XX w.”; Felicjan Bylok (Górnośląska Wyższa Szkoła Handlowa im. W. Korfantego w Katowicach), „Idea kształcenia ustawicznego i jego uwarunkowania rozwoju w Polsce”; Anna Grajpel (AJD), „Problem regionalizmu, wielokulturowości i międzykulturowości w edukacji muzycznej”; Sylwia Kita (AJD), „Szkoła w obliczu seksualizacji kultury masowej”; Adrianna Sarnat-Ciastko (AJD), „Tutoring opiekuńczy w perspektywie przemian kulturowych”; Maria Janukowicz (AJD), „Metafory szkoły w perspektywie wielokulturowej”; Paweł Zieliński (AJD), „Edukacja międzykulturowa Wietnamczyków w Polsce z uwzględnieniem dzieci z rodzin polsko-wietnamskich"; Iwona Olszówka (Specjalny Ośrodek Szkolno-Wychowawczy nr 1 w Częstochowie), „Działalność rewalidacyjna w Specjalnym Ośrodku Szkolno-Wychowawczym”; Katarzyna Zalas (AJD), „Rola autorytetu rodziców w wychowaniu dziecka”; Wioletta Sołtysiak (AJD), „Technologie informacyjne jako narzędzie komunikacji między różnymi kulturami”.

W dyskusji najwięcej zainteresowania wzbudziły wystąpienia K. Jakubiaka (rozumienie kategorii „charakter narodowy”), A. Grajpel (kwestia obecności muzyki polskiej w programach kształcenia polskich szkół muzycznych), F. Byloka (obecność kształcenia ustawicznego w programach kształcenia szkolnego) i S. Kity (kwestia wiarogodności badań dotyczących wieku inicjacji seksualnej młodzieży w Polsce).

W sekcji zaś III, poświęconej dziejom edukacji, której przewodniczył Adam Rosół (AJD), uczestnicy konferencji mieli okazję wysłuchać wystąpień: Mariana Cieślarczyka (Akademia Obrony Narodowej w Warszawie): „Edukacja dla zrównoważonego rozwoju postrzegana w perspektywie kulturowej”; Kazimierza Rędzińskiego (AJD), „Szkolnictwo żydowskie w guberni piotrkowskiej na przełomie XIX i XX wieku"; Mirosława Łapota (AJD), „Działalność Zakładu dla Żydowskich Dzieci Czterozmysłowych w Bojanowie Wielkopolskim w okresie międzywojennym"; Aleksandry Siedlaczek-Szwed (AJD), „Działalność żydowskich towarzystw na Wileńszczyźnie w Drugiej Rzeczypospolitej”; Ewy Golbik (Gliwicka Wyższa Szkoła Przedsiębiorczości): „Społeczno-pedagogiczny wymiar kryzysu współczesnego człowieka w środowisku miejskim”; Grażyny Miłkowskiej (Gliwicka Wyższa Szkoła Przedsiębiorczości), „Kontrowersje wokół edukacji dzieci romskich na terenie województwa śląskiego”; Izabeli Wrony (AJD), „Młodzieżowe organizacje ideowo-polityczne w Częstochowie w latach PRL-u"; Lilii Ogilczenko (Centralne Państwowe Archiwum Historyczne Ukrainy we Lwowie), „Działalność kulturalno-oświatowa w ukraińskim obozie dla uchodźców wojennych w Gmünd (1914-1918)"; Haliny Gromowej (CDIAL, Lwowski Uniwersytet Narodowy im. I. Franko), „Działalność społeczno-kulturalna Ukraińskiej Rady Kultury w Wiedniu (1914-1918)” oraz Marioli Mirowskiej (AJD), „Praca socjalna w przestrzeni edukacyjnej”.

Konferencję zakończono podsumowaniem obrad i dyskusji oraz uroczystą kolacją. Organizatorzy poinformowali uczestników spotkania, że referaty zostaną opublikowane 
w tomie pokonferencyjnym. Zatem z ich treścią będą mogły się zapoznać wszystkie osoby zainteresowane sprawami edukacji wielokulturowej. Wydaję się, iż formuła konferencji daleka jest od wyczerpania, można zatem spodziewać się kolejnej, VII już, edycji międzynarodowego spotkania naukowców w częstochowskiej Akademii im. Jana Długosza.

Izabela Wrona

\section{„Wychowanie w rodzinie. Konteksty historyczne i współczesne” konferencja naukowa Uniwersytetu Wroclawskiego i Kolegium Karkonoskiego (Jelenia Góra - Szklarska Poręba, 27-28 maja 2010)}

W dniach 27-28 maja 2010 r. w Jeleniej Górze odbyła się Międzynarodowa Konferencja Naukowa pt. „Wychowanie w rodzinie. Konteksty historyczne i współczesne”. Konferencja zorganizowana została przez Zakład Historii Edukacji Instytutu Pedagogiki Uniwersytetu Wrocławskiego oraz Wydział Humanistyczny Kolegium Karkonoskiego w Jeleniej Górze.

Konferencję zainaugurować jej inicjatorka i promotor prof. dr hab. Stefania Walasek (Uniwersytet Wrocławski). Następnie dr Leszek Albański (Kolegium Karkonoskie) powitał zebranych gości oraz uczestników.

Konferencję rozpoczęły obrady plenarne, których moderatorem była prof. dr hab. Dorota Żołądź-Strzelczyk (UAM Poznań). Interesujące wystąpienie wygłosił prof. dr hab. Wiesław Jamrożek (UAM Poznań i ŁWSH w Żarach) na temat „Rodziny w poglądach działaczy i teoretyków galicyjskiej socjalnej demokracji”. Prof. dr hab. Krystyna Ferenz (Uniwersytet Wrocławski) zainteresowała zebranych referatem „Komunikacja niewerbalna w rodzinie jako wyraz więzi". Goście z Republiki Czeskiej, profesorowie Uniwersytetu Masaryka w Brnie - Maria Mareckova i Jaroslav Vaculik, rozważali fenomen rodziny w Europie Środkowej. Prof. Vaculik przedstawił sytuację rodzin Czechów na Wołyniu. Obrady plenarne zakończyła dyskusja.

Po przerwie uczestniczy udali się na debaty w następujących sekcjach tematycznych:

I. Rodzina w tradycji i kulturze polskiej

Podsekcja 1 - Rodzina i wychowanie dzieci w XIX wieku (moderator: prof. dr hab. Barbara Jędrychowska). Wystąpienia odnosiły się do miejsca, roli rodziny, kobiety, wychowania na łamach czasopiśmiennictwa i podręczników oraz rodziny jako środowiska edukacyjnego.

Podsekcja 2 - Rodzina w latach II Rzeczypospolitej (moderator: prof. dr hab. Krzysztof Jakubiak). Obszarem zainteresowań uczestników było kształtowanie pedagogiki rodziny w II RP; tematyka rodziny w elementarzach, publikacjach J. Becka, programach 